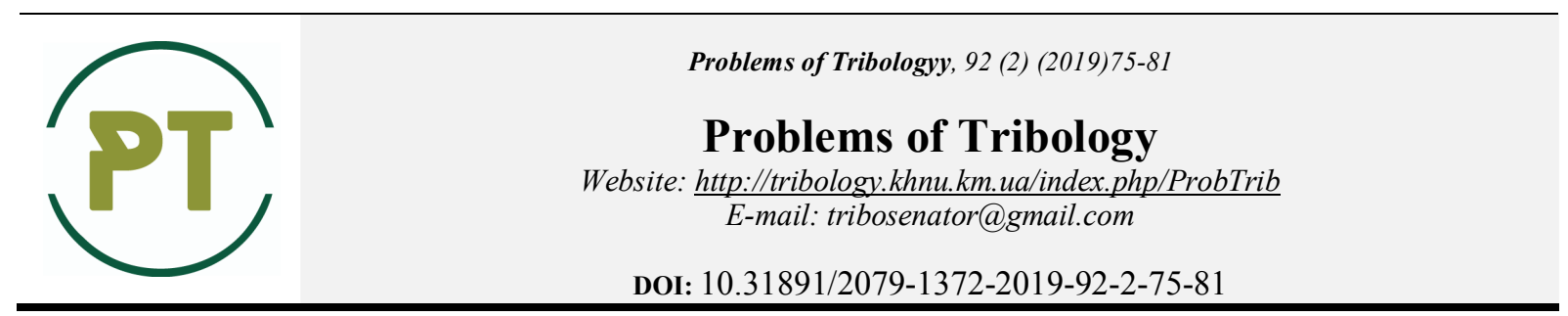

\title{
Polymeric composites of tribotechnical purpose based on fluoropolymers
}

\author{
O.S. Kabat ${ }^{1,2^{*}}$, O.D. Derkach ${ }^{2}$, N.V. Pavlushkina ${ }^{1}$, I.I. Pikula ${ }^{1}$ \\ ${ }^{1}$ Ukrainian State University of Chemical Technology, Dnipro, Ukraine \\ ${ }^{2}$ Dnipropetrovsk State Agrarian and Economic University, Dnipro, Ukraine \\ *E-mail: Amber_UDHTU@i.ua
}

\begin{abstract}
The increasing of reliability of friction units in machines and mechanism is actual task. One of the methods it decisions is creation new materials of tribotechnical purpose with high level of wear resistance. The polymer and polymeric composites (PC) based on it are progressive materials for using in friction units. It has many advantages such as high level of wear and chemical resistance, low density, low prime price and oth. In this work had been created PC of tribotechnical purpose based on Teflon and silica. It had been established optimal concentration of silica in polymer matrix $(10 \%$ mas.) when friction pair PC-steel had been high level of tribological properties. It had been investigated morphological of steel surface before and after wear with PC and had been established that decreasing of friction coefficient and wear is is related with creation of "antifrictional coating" on steel surface. It had been investigated influence of external factors (loading, velocity) on friction and wear of PC $(90 \%$ teflon $+10 \%$ silica). It had been established that this PC can work in normal regime under loading to 2,0 MPa and velocity 1,25 $\mathrm{m} / \mathrm{s}$. With help of MathCAD had been receive mathematical formulas that describe friction and wear of PC (90\% teflon $+10 \%$ silica). It had been investigated physico-mechanical and termophysical properties. It had been established that PC with silica have high level of properties if compare with initial polymer. It had been recommendation by the introduction of investigated materials in friction units of machines and mechanisms.
\end{abstract}

Keywords: friction units, teflon, polymeric composites, tribological properties, physico-mechanical properties

\section{Introduction}

Consumption ability of present society is rising from year to year. Due to their satisfaction enterprises are using machines and mechanisms with high level of productivity, which are, in common cases, are really energy demanding (it's known, that energy, which is consuming by equipment up to $70-80 \%$ expends on compensation of losses on friction of assembles of machines and mechanisms)[1]. Rising level of machines' and mechanisms' output very occurs often, because of the intensification of their main units, as follows this bring to decreasing in reliability.

Therefore, reduction of friction losses in machines' and mechanisms' joints and increase of their reliability, they are important and actual tasks.

There are two ways to solve the issue:

- development and implementation of new structural friction assembles of machines and mechanisms;

- creating new materials with high level of tribological features for friction assembles.

Design and application of new structural machine's and mechanism's friction unites are quite complicated from material point of view. For this reason, in a majority of case, this leads to a significant change in the design of existing equipment and increase its cost. Thus, this option is not always appropriate for use.

Creating new materials for machine's and mechanism's friction unites does not require significant investments that are connected with the change in their designs. And in a few cases it allows not only reduce the resistance to friction, increase the reliability of machines and mechanisms, but also improve their operational characteristics. This happens cause to ability of such materials work in the condition high levels of loading, temperatures and slip rates, in aggressive, abrasive environments and in friction modes without lubrication procedure and with limited lubrication as well.

One of the most future-oriented materials, which can decrease friction and increase level of reliability of machines' and mechanisms joints are polymers and polymer composites (PC) on their basis [2-6]. By contrast 
with traditional materials, they used in friction units (metals and their alloys) they have less weight, they are more technologic at the processing into finished products (in response more cheaper), they are able to work in aggressive and abrasive conditions with no greasing and modes with limited use of lubricants.

Polymers having the best level of tribological properties as refer to fluoropolymers and PC based on them. In the modern industry, PolyTetraFluoroEthylene (PTFE) is the most wide spreading along with fluoropolymers, they filled with graphite, carbon fiber, dispersed metals, etc. [7-9] In the meanwhile, these composites have a number of disadvantages, termed, a rather high level of cost and low level of physical, mechanical and thermophysical properties. We can assume, that the actual task is to develop a PC based on PTFE, which is withhold of these disadvantages and can be used in the machines and mechanisms' friction units.

\section{Materials}

Fluoropolymer of mark PTFE has selected as polymer base. It is a result of polymerization of tetrafluoroethylene and that is white-blue color powder with pour density $0,35-0,45 \mathrm{~g} / \mathrm{sm} 3$.

As a filler amorphous silica - silica gel used. Which was obtained from dried, washed and crushed gel, which and created by acidification of aqueous-alkaline solution of metasilicate sodium. The resulting filler has a well-developed surface with the main particle size 5-10 mkm (Fig. 1).

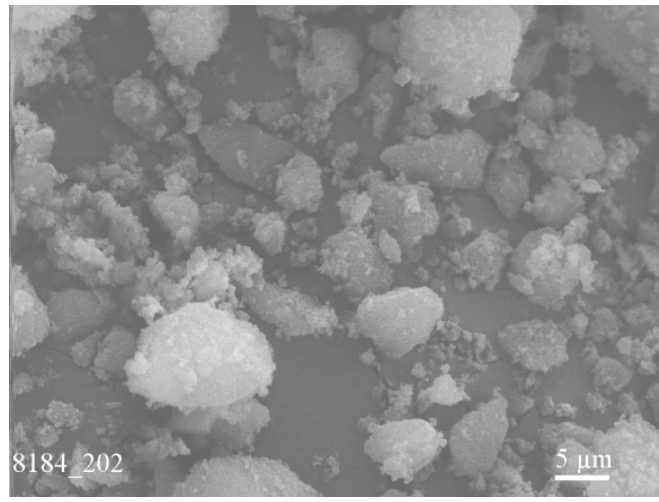

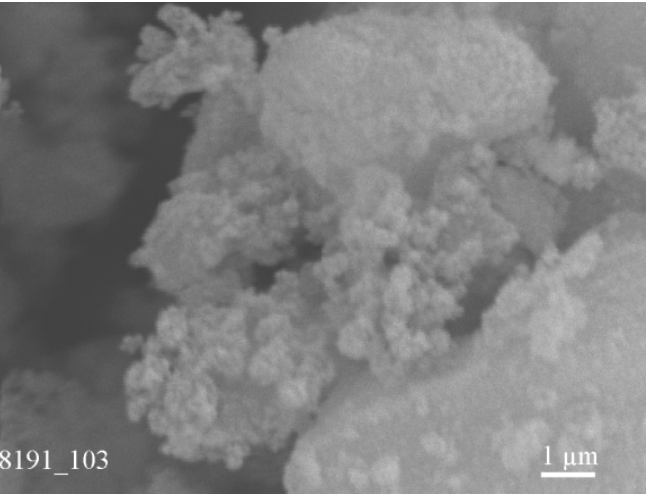

$\mathrm{b}$

Fig. 1. Microphotographs of particles of silica gel

\section{Research methods}

Researches of morphology of fillers' particles and friction surfaces were done on electric (Superprobe733 (Jeol)) and optical (МИМ-7) microscopes. Coefficient of friction and intensity of linear wear at the friction engagements of designed PC with steel defined with aid of machine "2070 CMT-1" at the friction regime without greasing according to scheme disk-block. We used steel sample of steel 45 with roughness of $\mathrm{Ra}=0,32$ mkm and firmness 45-50 HRC. Density of materials defined by methods of hydrostatic weighing in accordance with ISO 1183-1. Compressive stress at yield $\left(\sigma_{\mathrm{y}}\right)$ of materials determinated on universal tensile testing machine 2167 P-50 as indicated in ISO 604. Hardness $(\mathrm{H})$ of materials determined by method of Shore scleroscope hardness on durometer 2013 TSHSP in accord with ISO-2039-1. Vicat softening temperature $\mathrm{T}_{\mathrm{VC}}$ on device FWV-633/10 as indicated in ISO 1183-1 defined.

\section{Discussion of research results}

One of the most perspective fillers for polymeric matrix is amorphous silica, which due sufficiently developed surface and active silanol groups on it able to raise its physical, mechanical and thermal properties [10]. It stands mention, that this filler is cheap and therefore can also significantly reduce the cost of the received PC. It is known studies [11-13] in which silica and materials based on it used as polymer fillers for the creation of PC, which change the nature of friction during frictional interaction with steel and greatly increase the reliability of units in which they operate.

A large scale of modifications of silicon oxides are known, which differ in the way of obtaining, morphology, dispersion, surface activity, and others. The most common modifications of silica include pyrogenic (obtained by the interaction of a gaseous four silicon chloride with water vapor) of the brand "aerosol" and hydrated (obtained from a sol or gel under the action of a water solution of siliceous gel with sodium acid) of the stamps "white soot" and " silica gel".

It is known from previous studies [14] that the best effect on the level of physico-mechanical, thermophysical and tribological properties of PC is carried out by silica gel. Thus, due to its introduction into the polymer matrix by $10-15 \%$ increase strength characteristics, heat and heat resistance, in 1,5-2 and 8-10 times, respectively, it reduce the coefficient of friction and the intensity of linear wear of PC. Therefore, it is interesting 
to investigate the effect of silica gel on the properties of PC on the basis of PTFE. Due to research PC with content of silica gel is gives as a 5 to $25 \%$ used, resulting from previous works $[14,15]$. Consequently, these materials develop for machines' and mechanisms' units and it require proceed with tribological research to this end determine the optimum content of the filler in the polymer. The research results presented in Fig. 2.
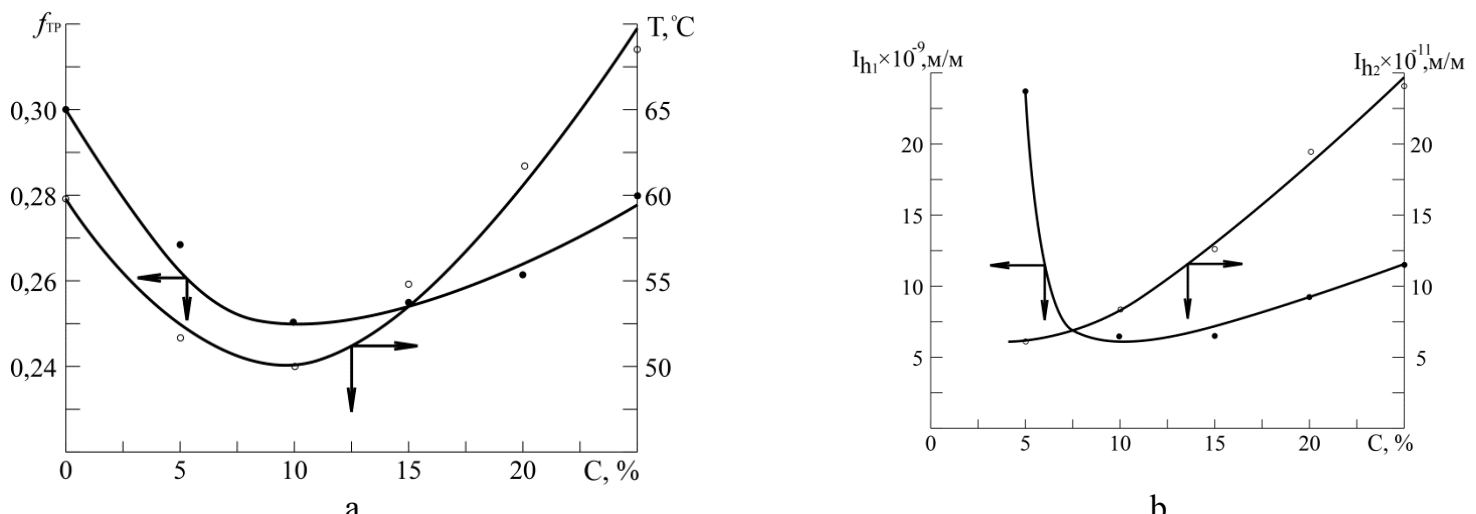

Fig. 2. Concentration (C) dependences (a) of the coefficient of friction $\left(f_{T P}\right)$, temperature on friction surface (T) and $(b)$ the intensity of linear wear PC $\left(I_{h 1}\right)$ and steel sample $\left(I_{h 2}\right)$

From conduct studies, we found, that adding silica gel in composition of PTFE leads to improve tribological characteristics of designed PC in condition of friction with steel. Thus wise, the coefficient of friction and temperature of the friction surface decreased by $15-20 \%$, and the intensity of linear wear of developed PC in 150-200 times less as compared with original polymer. With an increase in the concentration of silica gel in PTFE, some increase in the intensity of steel sample wear is observed, which is associated with the abrasive effect of the hard filler on the steel. Moreover, it is not very intense with a filler content of up to $10 \%$ and significantly increasing concentrations of silica gel in PTFE.

It stands for that the obtained concentration dependences (Fig. 2) can be seen an extremum of properties in the area of $10 \%$ of silica gel in PTFE. At this concentration of the filler in the polymer, the minimum values of the coefficient of friction, temperature on the surface of friction and the intensity of linear wear are observed. That is, the optimal concentration of silica gel 1 in PTFE, in terms of tribological properties of PC developed, is $10 \%$ by weight.

Tribological properties of developed PC compared to the original polymer was being improved at the friction interaction with steel is the result of the impact of filler, both PC and the nature of friction. To install it, studies on investigation of the steel friction surface morphology before and after frictional interaction with PTFE and PC based on it was commited. (Fig. 3).

Based on the microphotographs we can make a conclusion, that friction surface of steel afther friction interaction with PTFE (Fig. 3b) is not dramatically different from the initial one (Fig. 3a) witch obtained during its preparation for research. And the friction surface after frictional interaction with PC on the basis of PTFE and silica gel (Fig. 3c) has significant differences from the previous, due to the frictional transfer of PC components on it and the creation of an "antifriction coating" that affects the friction and reduces the friction coefficient and the wear rate of the PC developed in comparison with the initial polymer in the frictional interaction with the steel.

The purpose of impact on concentration of silica gel in PTFE on the tribotechnical characteristics of the friction unit PC - steel was to study the microhardness and roughness of the steel surface after friction with PC with different filler contents. It is defined (Fig. 4) that the microhardness and roughness of the steel surface after friction with PC increased, as evidenced by the creation of an "antifriction coating" on the steel surface as a result of tribochemical reactions at the friction and mechanical action of the filler on the steel surface.

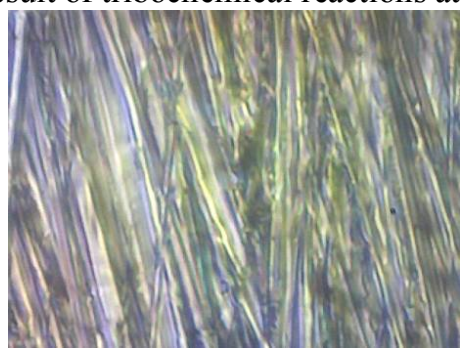

$\mathbf{a}$

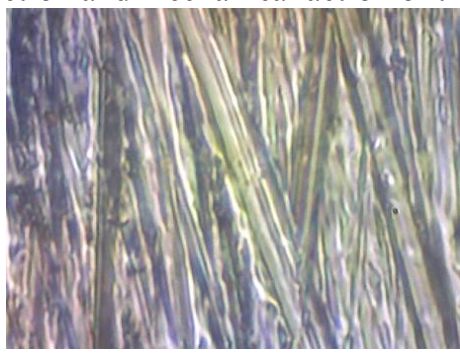

$\mathbf{b}$

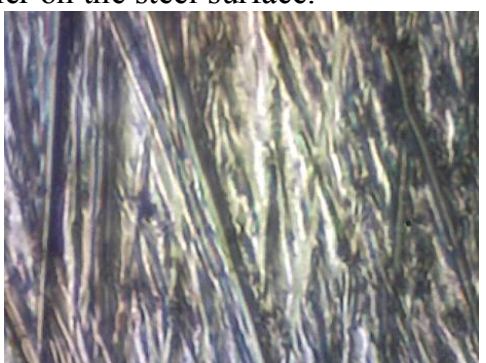

c

Fig. 3. Microphotographs of steel surface before (a) and after (b,c) frictional interaction with (б) PTFE and (c) PC based on PTFE and silica gel. Magnification in 400 times. 
In the investigated friction pairs "PC-steel" the increase of the content of the filler in the PC up to $10 \%$ leads to an increase in the microhardness of the steel surface after frictional interaction with the PC. So its maximum value after friction with $90 \%$ PTFE $+10 \%$ silica gel composite reaches $610 \mathrm{MPa}$. A further increase in the concentration of the filler in the $\mathrm{PC}$ has up to $25 \%$ and lead to a slight decrease in the microhardness of the steel surface after frictional interaction with the PC, which was probably due to the destruction of the "antifriction coating" under the influence of a large amount of filler that falls into the friction zone. The value of the roughness of the steel surface after frictional interaction with the developed PC increases from 0,22 to 0,27 mkm with increasing concentrations of filler in PC from 0 to $25 \%$ by weight. It should be noted that increasing the roughness of the steel surface after friction with PC with the contents of the filler from 0 to $10 \%$ is more intense than with increasing the concentration of filler from 10 to $25 \%$. That is due to the creation of a stable "antifriction coating" on the steel surface when rubbed with PC with a filler content of $10 \%$ or more.

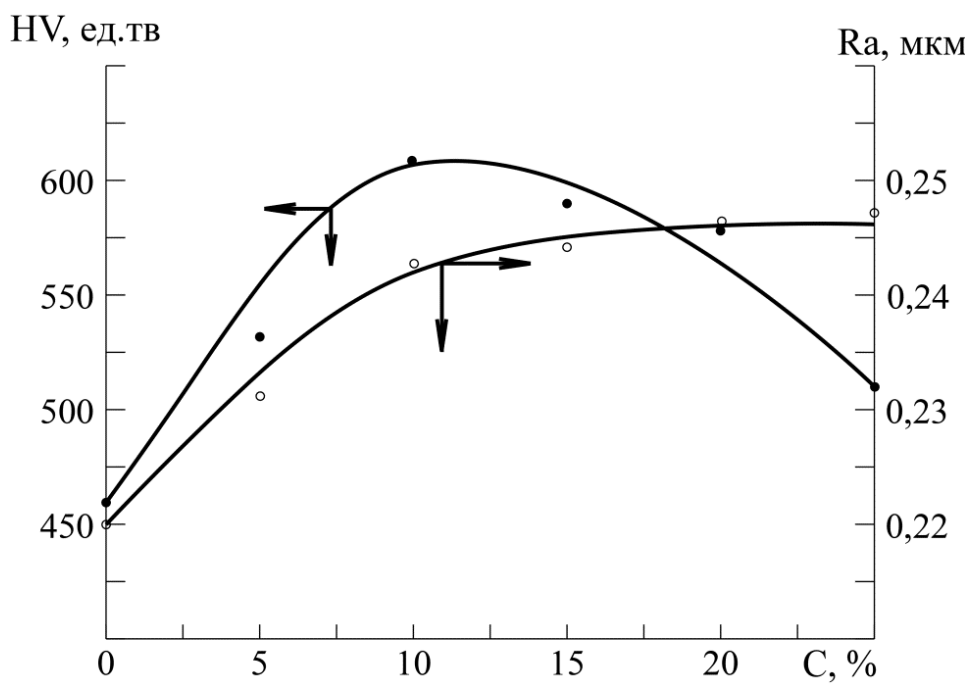

Рис. 4. Dependences of microhardness (HV) and roughness (Ra) of the steel surface from concentration of silica gel in PTFE before and after friction interaction with $\mathrm{PC}$

It should take note of that on the obtained dependences (Fig. 4), the microhardness and roughness of the steel surface after the friction interaction with the developed PC, there are extremes in the area of the contents of the filler $10 \%$. This correlates with the nature of the concentration dependences of the coefficient of friction, the temperature on the surface of the friction and the intensity of the linear wear (Fig. 2) and indicates the creation of the most favorable friction conditions in the frictional interaction of PC on the basis of PTFE and silica gel with steel.

For the feather investigations, it had been choosen PC with 10\% of silica gel because this PC have the best tribological features during interaction with steel.

To determine the maximum values of loads and velosities at which a pair of friction developed by "PCsteel" will work reliably conducted tribotechnical investigations on their influence on the coefficient of friction and the intensity of linear wear developed by PC. The results of investigations are shown in Fig. 5.

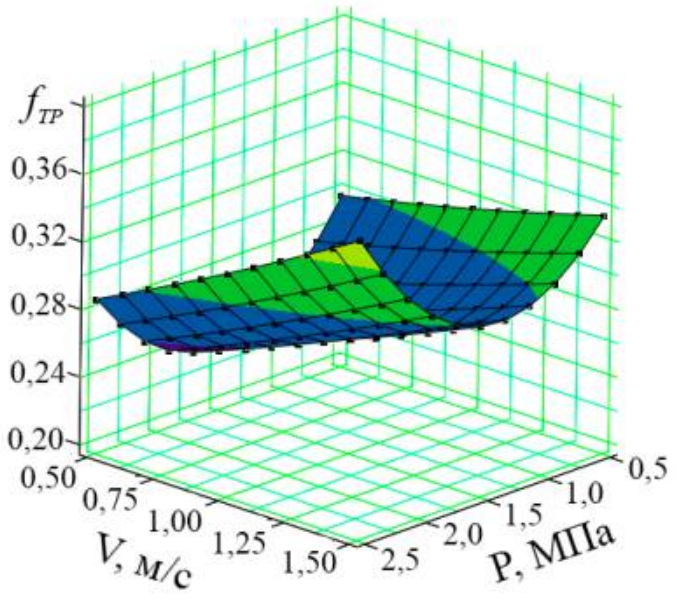

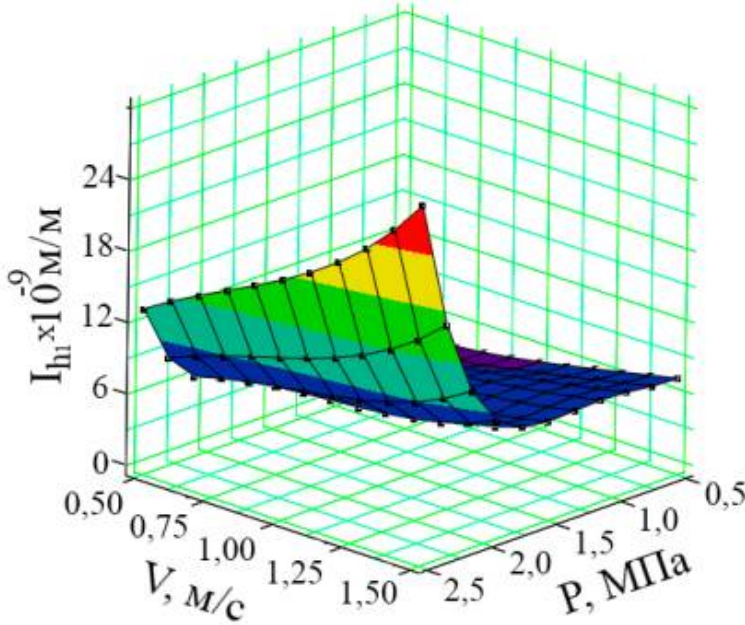

b

Puc. 5. Dependences of (a) the coefficient of friction $\left(f_{T P}\right)$ and $(b)$ the intensity of linear wear $\left(I_{h 1}\right)$ of material $(90 \%$ PTFE $+10 \%$ silica gel) from loadings $(P)$ and velocities $(V)$ in time of friction interaction with steel 
Owing to results of investigations, the coefficient of frictions and intense of linear wear of the investigated material varies slightly with loads from 0,5 to $2 \mathrm{MPa}$ and velocity rates from 0,5 to $1,25 \mathrm{~m} / \mathrm{s}$. That examine to the normal friction mode of the frictional interaction of the PC developed with steel. Further increase in load and velocity leads to a significant increase in the coefficient of friction and the intensity of linear wear of the $\mathrm{PC}$, it is indicating the start of a friction emergency, in which there is a rapid destruction of the material and the possible jamming of the friction units, wherein they operate.

To simplify the determination of the key tribotechnical parameters in the friction of the developed PC on the steel by MathCAD program mathematical description of the coefficient of friction and the intensity of linear wear on the load and slip speed at the friction point obtained. It taken below:

$$
\begin{gathered}
f_{T P}=0,058 \cdot P^{2}+0,0075 \cdot V^{2}+0,023 \cdot P \cdot V-0,191 \cdot P+0,013 \cdot V+0,363 \\
\begin{array}{c}
I_{h l}=4,292 \cdot P^{5}-1,738 \cdot V^{5}-26,082 \cdot P^{4}+31,088 \cdot V^{4}+54,856 \cdot P^{3}-90,22 \cdot V^{3}- \\
-52,401 \cdot P^{2}+98,896 \cdot V^{2}+28,686 \cdot P-44,869 \cdot V+1,12 \cdot P^{4} \cdot V-0,427 \cdot P \cdot V^{4}+ \\
+2,24 \cdot P^{3} \cdot V-19,291 \cdot P \cdot V^{3}+5,642 \cdot P^{2} \cdot V+50,065 \cdot P \cdot V^{2}-2,133 \cdot P^{3} \cdot V^{2}+ \\
+10,057 \cdot P^{2} \cdot V^{3}-19,755 \cdot P^{2} \cdot V^{2}-31,181 \cdot P^{1} \cdot V^{1}+6,679
\end{array}
\end{gathered}
$$

Use the formulas 1 and 2 can serve not only to figure out the coefficient of friction and the intensity linear wear of $90 \%$ PTFE $+10 \%$ silica gel in material at the friction engagements with steel in studied intervals of loads and velocities $(\mathrm{P}=0,5 \div 2,5 \mathrm{MPa} ; \mathrm{V}=0,5 \div 1,5 \mathrm{~m} / \mathrm{s})$. Also to predict the behavior of friction pairs in the ambient conditions of work, that extends beyond limits of investigated interval.

It is of interest to define physico-mechanical and termophysical properties of material with the highest level of tribological properties (90\% PTFE+ $10 \%$ silica gel) and to compare them with unfilled PTFE. Findings of research performed in the table.

According to results, the provision of silica gel in PTFE contribute to increasing of physico-mechanical and termophysical properties obtaining PC. The enhancing effect of filler on polymer matrix explaining by physical interactions silica gel with molecules of polymer at the processing of received PC into finished products.

Table 1

Physico-mechanical and termophysical properties of unfilled PTFE and PC (90\% PTFE + 10\% silica gel)

\begin{tabular}{|c|l|c|c|}
\hline \multirow{2}{*}{ № } & \multicolumn{1}{|c|}{ Properties } & \multicolumn{2}{|c|}{ Material } \\
\cline { 3 - 4 } & & PTFE & $\begin{array}{c}\text { 90\% PTFE }+10 \% \text { silica } \\
\text { gel }\end{array}$ \\
\hline 1 & Density $\rho, \mathrm{kg} / \mathrm{m}^{3}$ & 2200 & 1940 \\
\hline 2 & Hardness $\mathrm{HB}, \mathrm{MPa}$ & 42 & 48 \\
\hline 3 & Compressive stress at yield $\sigma_{\mathrm{y}}, \mathrm{MPa}$ & 12 & 14 \\
\hline 4 & $\begin{array}{l}\text { Modulus of elasticity in compressive } \mathrm{E}, \\
\mathrm{MPa}\end{array}$ & 610 & 890 \\
\hline 5 & Vicat softening temperature $\mathrm{T}_{\mathrm{VC}},{ }^{\circ} \mathrm{C}$ & 164 & 184 \\
\hline
\end{tabular}

On the assumption of research carried out, it is possible to recommend PC $(90 \%$ PTFE $+10 \%$ silica gel $)$ for industrial implementation purpose into friction units, vehicles and mechanisms, witch are working in demanding conditions at steady and dynamic loadings, high sliding velocities, with the wide range of temperature $\left(-40\right.$ до $\left.150^{\circ} \mathrm{C}\right)$ with the transfer the friction assembles to the work in condition without application of lubricants.

\section{Conclusion}

PC based on PTFE and silica gel has developed for tribotechnical purposes. According to the results of tribotechnical investigations, the optimum concentration of the filler in the polymer is $10 \%$ by mass. The morphology of the steel surface of friction before and after frictional interaction with the PC has been studied and it has found that it'd created an "antifriction coating" that helps to improve the tribotechnical characteristics of the friction pair "PC-steel" in comparison with the friction pair "PTFE-steel". The maximum load values (2,0 $\mathrm{MPa})$ and velocity $(1,25 \mathrm{~m} / \mathrm{s})$ where in details base on designed PC will work in friction assembles of machines and mechanisms in normal operation work. With aid of program MathCAD provides mathematical dependencies that describe the effect of external factors (load, velosity) on friction and wear of PC $(90 \%$ PTFE $+10 \%$ silica gel). The basic physico-mechanical and termophysical properties have been determined and it has established that the silica gel has an enhancement effect on PTFE, it is increasing the level of Compressive stress at yield, the elastic modulus, the hardness and Vicat softening temperature by $5-15 \%$ in comparison with the PTFE. The recommendations have been provided for the implementation of the created PC into friction units of machines and mechanisms. 


\section{References}

1. Garkunov D.N. Tribotehnika(iznos i beziznosnost). - M.: Mashinostroenie, 1985. - 424 s. (in Russian).

2. The wear resistance improvement of fibre reinforced polymer composite gears / Mao K., Greenwood D., Ramkumar R. and oth. // Wear. - 2019. - Vol. 426-427. - P.1033-1039.

https://doi.org/10.1016/j.wear.2018.12.043

3. Advanced polymeric coatings for tilting pad bearings with application in the oil and gas industry / L. Pixiang, J. L. Meyer, B. Vaezian, A. A. Polycarpou // Wear. - 2016. - Vol. 354-355. - P.10-20.

https://doi.org/10.1016/j.wear.2016.02.013

4. Polymer Composite Materials for Friction Units of Space and Aviation Engineering / Kabat O. S., Sitar V.I., Ermachenko D.V. and so on. // System design and analysis of aerospace equipment characteristics: a collection of scientific works of the Dnipro National University named after. O. Gonchar. - 2017. - Tom. XXIII. - P. 40-48. (in Ukrainian).

5. Kabat O., Sytar V., Sukhyy K. Antifrictional polymer composites based on aromatic polyamide and carbon black // Chemistry \& chemical technology. - 2018. - Vol.12. - № 3. - P. 326-330.

https://doi.org/10.23939/chcht12.03.326

6. Influence of operating modes on wear of parts made of polymeric-composite material / VV Aulin, O.D. Derkach, D.O. Makarenko, AV Grinkov // Problems of tribology. - 2018. Volume 90. No. 4. p. 65-69 (in Ukrainian).

7. Kabat O. S., Dusheyko MV Polymer composite materials of special purpose based on fluoroplastics // Technological systems. - 2017. - Vol. 4 (81). - P. 63-67. (in Ukrainian) [dx.doi.org/10.29010/081.8]

8. Preparation and tribological properties of hybrid PTFE/Kevlar fabric self-lubricating composites / Liu Y., Xu N., Wang Y. and oth. // Surface and Coatings Technology. - 2019. - Vol. 361. - P.196-205. https://doi.org/10.1016/j.surfcoat.2018.12.121

9. A novel assembly of $\mathrm{MoS}_{2}$-PTFE solid lubricants into wear-resistant micro-hole array template and corresponding tribological performance / A.H.Wang J.Xia Z.X.Yang D.H.Xiong // Optics \& Laser Technology. - 2019. - Vol. 116. - P.171-179. https://doi.org/10.1016/j.optlastec.2019.03.033

10. Ayler R. Himiya kremnezema: Per. s angl. - M.: Mir, 1982. - 1127 s. (in Russian)

11. Sucheninov P.A., Adamenko N.A.,Sergeev D.V. Razrabotka i issledovanie kompozitsionnyih materialov dlya uplotneniy vozdushnyih porshnevyih kompressorov // Izvestiya VolgGTU. - 2009. \#. 11(59). Vyip 3, S. 66-69. (in Russian).

12. Syitar V.I., Kabat O.S. Teplostoykie materialyi tribotehnicheskogo naznacheniya na osnove aromaticheskogo poliamida i dispersnyih kremnezemov // Voprosyi himii i himicheskoy tehnologii. - 2007. \#4. - S.94-98. (in Russian).

13. Beckford S., Wang Y.A., Zou M. Wear-resistant PTFE/SiO2 nanoparticle composite film // Tribology Transactions. - 2011. - Vol. 54, Issue 6. - P. 849-858. https://doi.org/10.1080/10402004.2011.606962

14. Kabat O.S., Syitar V.I., Mitrohin A.A. Termostoykie polimernyie kompozityi spetsialnogo naznacheniya dlya tyazhelonagruzhennyih uzlov treniya // Tehnologicheskie sistemyi. - 2017. - T. 2 (79) - S. 25-33. (in Russian).

15. Sitar V.I., Kabat O.S. Investigation of the influence of finely dispersed silica gel on the properties of aromatic phenylene polyamide // Problems of chemistry and chemical technology. - 2005. - №1. - C.199-203. (in Ukrainian). 
Кабат О.С., Деркач А.Д., Павлушкина Н.В., Пикула И.И. Полимерные композиционные материалы триботехнического назначения на основе фторполимеров

Повышение уровня надежности узлов трения машин и механизмов является актуальной задачей. Одним из способов ее решения является применениеи в них новых материалов триботехнического назначения с высоким уровнем износостойкости. Известно, что наиболее прогрессивными материалами для узлов трения являются полимеры и полимерные композиционные материалы (ПКМ) на их основе. К их преимуществам следует отнести возможность работы в узлах машин и механизмов без смазывания или при граничном смазывании, высокую износостойкость, химическую стойкость, небольшую массу и др. В работе разработаны ПКМ триботехнического назначения на основе фторопласта-4 и силикагеля. Найдена оптимальная концентрация наполнителя $(10 \%$ мас.) в полимерной матрице при которых пара трения ПКМ-сталь имеет наибольший уровень триботехнических характеристик. Исследовано морфологию и свойства стальной поверхности до и после фрикционного взаимодействия с разработанным ПКМ и установлено, что уменьшение коэффициента трения и износа ПКМ связано с образованием “антифрикционного покрытия" на стальной поверхности пары трения. С целью установления влияния внешних факторов (нагрузка и скорость скольжения) на терние и изнашивание материала $90 \%$ фторопласт- $4+10 \%$ силикагель проведены его триботехнические исследования при фрикционном взаимодействии со сталью. Установлено, что разработанный материал может работать в нормальном режиме работы в узлах трения машин и механизмов при нагрузках до 2,0 МПа и скоростях скольжения до 1,25 м/с. При помощи программы MathCAD получено математическое описание процесса трения и изнашивания материала $90 \%$ фторопласт-4 + 10\% силикагель по стали в исследованном интервале нагрузок и скоростей скольжения. Исследованы его физико-механические и теплофизические свойства и установлено, что введение наполнителя в полимер способствует повышению напряжения при пределе текучести при сжатии, твердости, модуля упругости и теплостойкости в сравнении с исходным полимером. Приведены рекомендации по применению разработанного ПКМ в узлы трения машин и механизмов.

Ключевые слова: узлы трения, фторопласт, полимерные композиционные материалы, трибологические свойства, физико-механические свойства 